\title{
ПРОБЛЕМА ПРЕДМЕТУ ТА МЕТОДІВ МУЗЕСЛОГЇ̈ ТА АЛЬТЕРНАТИВНІ ПОГЛЯДИ
}

\author{
Віталій КУШНІР \\ Національна академія наук України \\ Інститут народознавства \\ проспект Свободи, 15, 79000, м. Львів, Україна \\ e-mail: vitaliy_val@ukr.net \\ Тарас МАРИСКЕВИЧ \\ Львівський національний університет імені Івана Франка \\ кафедра історичного краєзнавства \\ вул. Університеттська, 1, 79000, м. Львів, Україна \\ e-mail: kf.kraeznavstva@gmail.com
}

\begin{abstract}
Проаналізовано відмінні погляди науковців на проблему предмету та методів музеєлогії. Визначено зміст інституційного, предметного та комплексного підходів, а також теорії музейної комунікації. Показано вплив на аналітичні роздуми сучасних музеєзнавців концепції музеяльности 3. Странскі. Зазначено, що частина музеєлогів дотримується погляду, що музеєлогія не має власного особливого методу та оперує сукупністю методів низки інших спеціяльних дисциплін. Натомість інші дослідники прагнуть виробити такий метод.

Ключові слова: музеєлогія, музеєзнавство, предмет музеєлогії, методи музеєлогії, концепція музеяльности.
\end{abstract}

Музеєлогія, чи музеєзнавство, вже не одне десятиліття займає своє місце серед сучасних академічних дисциплін. Ї̈̈ викладають у багатьох вищих навчальних закладах, а фахівці, у тому числі й українські, підготували численні підручники та навчальні посібники. У сучасній системі організації наукового знання та установ освіти, музеєлогія стоїть поруч із культурологією, соціологією, мистецтвознавством та низкою суміжних гуманітарних дисциплін.

3 іншого боку, для більшости соціогуманітарних “секторів” науки питання про їх розмежування з іншими завжди було та залишається предметом дискусії. Проте, що стосується саме музеєлогії, проблеми точного та вичерпного визначення її предмету, так само як і нерозривно пов'язаного із нею завданням сформувати власну дослідницьку методологію, то діяпазон відмінностей у поглядах дослідників $\epsilon$, як видається, особливо широкий.

Щоб окреслити актуальний стан справ у теоретичній музеєлогії, впливовий нідерландський музеєзнавець Петер ван Менш використав досить рішуче визначення - “концептуальний і методологічний хаос", ознаками якого він вважає такі моменти: відсутність підручників з теорії музеєлогії, поверхневий характер викладу ключових проблем, що зафіксовані лише у загальному вигляді 
ISSN 2078-6077. Наукові зошити історичного факультету Львівського університету. 2018-2019. Випуск 19-20. Proceedings of History Faculty of Lviv University. 2018-2019. Issue 19-20.

у відповідних посібниках, а також циклічність в обговоренні ключових проблем науки ${ }^{1}$.

Попри довгу історію розвитку музеєлогії, і сьогодні, зазначив ван Менш, “багато музейних працівників... відмовляються приймати ідею про те, що музеєлогія $є$ чимось більшим, ніж набором практичних вмінь та навичок. Однією 3 основних причин такого скепсису стосовно визначення автономного статусу музеєлогії як наукової дисципліни є ії тісний зв'язок, з одного боку, з областю музейної роботи, а з іншої, з профільними дисциплінами, що визначають специфіку конкретних музейних колекцій"2.

Зауважимо, що сам дослідник скептичного погляду на науково-методологічну самостійність музеєлогії не поділяс. 3 його точки зору, цілу ії історію “можна описати як процес поступової емансипації, що охоплює розрив музеєлогії 3 профільними дисциплінами та формування нею когнітивної орієнтації $\mathrm{i}$ методологіï”’. Попри це, на думку П. ван Менша, “хоча <...> перехід від емпірично-описової до теоретично-синкретичної стадії розвинувся і почався близько 1870 р., музеєлогія як самостійна академічна дисципліна досі нездобула загального визнання. Чимало музейних працівників все ще відкидають саму думку про це"4. "Музеєлогія, - писав П. ван Менш, - навіть тоді, коли вже ніхто не сумнівався у іiі науковому статусі, - розглядалася в ролі прикладної науки. Концептуальні рамки профільних дисциплін сприймали як цілком достатні для музейної роботи; музеєлогії як такій власні концептуальні рамки були непотрібні”'s.

Російський музеєзнавець Ольга Сапанжа зазначала: “Становище музеєлогії в сучасному науковому дискурсі $є$ двозначне. 3 одного боку, її статус $\epsilon$ безперечним, і музеєлогія стверджує свої позиції із власним об'єктом, предметом і методом досліджень. Доказом цього $є$ заснована на концепціях східноевропейської школи музеєлогії одностайність у питаннях об'єкта, предмета і структури науки, яке демонструють у навчальних посібниках з музеєлогії, музеєзнавства, музейної справи. 3 іншого боку < .. >, дослідження, які дозволили б зрозуміти, де проходять межі музеєлогії, не настільки авторитетні. Монографій 3 окремих проблем музеєлогії дуже мало, що ставить під сумнів існування спеціяльної методології музеєлогії, а отже і самої науки"б.

Дослідниця писала про теперішній етап розвитку музеєзнавства як про “етап проходження своєрідної “точки біфуркації”, коли накопичений практичний

\footnotetext{
${ }^{1}$ Петер ван Менш, “К методологии музеологии”, Вопросы музеологии, № 1 (9), (2014): 17.

2 Петер ван Менш, “Дискурс музеологии”, Вопросы музеологии,№ 1 (9), (2014): 21.

${ }^{3}$ Ibidem, 21.

${ }^{4}$ Ibidem, 27.

${ }^{5}$ Ibidem, 23.

${ }^{6}$ Ольга Сапанжа, “Современная российская музеология: тактические итоги и стратегические форсайты”, Веснік Беларускага дзяржаунага універсітэта культуры і мастацтвау, № 2 (24), (2015): 182. (Тут і далі переклад з російської автора).

${ }^{7}$ Точка біфуркації - такий критичний стан системи, за якого вона є дуже нестійкою, і може або перейти у хаотичний стан, або сягнути нового тривалого рівня впорядкованости та стабільности.
} 
матеріял вимагає не лише підсумування, але подальшого розвитку основ науки, пов'язаний з певними концептуальними перебудовами"в.

Наголос на різноманітності поглядів на предмет музеєлогії, їх величезній "різновимірності", строкатості, утворює, мабуть, один з основних спільних моментів у публікаціях, що стосуються музеєлогічної теорії. Попри це, можливо виділити найвпливовіші точки зору, певні найпомітніші течії в музеєлогічному теоретизуванні. Сьогодні базис широкого спектру дослідницького розуміння основного змісту музеєлогії утворюють кілька альтернативних підходів, у рамках яких стрижнем аналітичного розгляду роблять відмінні виміри музейництва. Хоча вони склалися в різний час, формування нових основ бачення музеєзнавства не призводило, проте, до цілковитого “усунення" інших концепцій, але радше розширювало та ускладнювало теоретичний інструментарій музеєзнавства. Відповідно до кожного з них, дослідники по різному обгрунтовують і своє розуміння основного предмету музеєлогії.

У 1975 р. В. Йенсен вказував на існування двох базових напрямків у відповідній дискусії. Згідно з першим, музеєлогія є наукою, яка вивчає інституційні ролі та функції музеїв різних видів. Другий підхід визначає музеєлогію як науку про музеяльність, що формує основи для практичної музейної роботи (докладніше пояснимо це поняття нижче. $-(B . K ., T . M .)^{9}$.

У 1981 р. чехословацький музеєзнавець Й. Бенеш зазначав, що різні музеєлогічні напрямки основою музеєлогії визнають: 1) музей; 2) музейний предмет; 3) музеяльність та 4) конкретні (профільні) дисципліни. Цей дослідник пропонував власний варіят, називаючи предметом для вивчення у музеєлогії “набір спеціялізованих форм діяльности" .

Східнонімецький музеєзнавець Е. Гофман вважав, що у музеєзнавстві ствердилися три базові підходи до розуміння свого предмету дослідження. Перший розуміє музеєлогію як вивчення музейних інституцій; другий - як вивчення музейних предметів, і третій - як вивчення музеяльности. Знаний радянський/російський музеєзнавець А. Разгон, узагальнюючи досвід музеєлогії соціялістичних країн Східної Европи, також називав, значною мірою повторюючи німецького колегу, три підходи: інституційний; предметний; комплексний, який “розглядає ставлення людини до музейного предмету” 1 . Власне, саме така систематизація альтернативних тлумачень змісту музеєлогії набула найбільшого поширення в музеєзнавчій літературі радянській/російській, а почасти і пострадянській.

Відомий чеський музейолог 3. Странскі систематизував погляди на предмет музеєлогії (за його обережним визначенням - відмінні “когнітивні інтенції”

\footnotetext{
${ }^{8}$ Цит. за.: Людмила Шляхтина, “Современная музеология: горизонты теоретизирования”, Вопросы музеологии, № 1 (7), (2013): 12

${ }^{9}$ Петер ван Менш, “Предмет музеологии”, Вопросы музеологии, № 1 (9), (2014): 65

${ }^{10}$ Ibidem.

${ }^{11}$ Петер ван Менш, “Предмет музеологии”, Вопросы музеологии, № 1 (9), (2014): 65.
} 
ISSN 2078-6077. Наукові зошити історичного факультету Львівського університету. 2018-2019. Випуск 19-20. Proceedings of History Faculty of Lviv University. 2018-2019. Issue 19-20.

музейологів) так: музей; форми музейної діяльности; музейна ідея (дослідження цілей та місії музею); збереження (тобто виявлення тих аспектів реяльности, що мають бути збережені в інтересах суспільства) ${ }^{12}$.

3 нашого погляду, вельми влучно стан справ узагальнив П. ван Менш: "різноманітність підходів до вивчення музеєлогії найкраще можна описати як певний континуум, з одного краю якого знаходиться переважно прагматичний, інституційний підхід, а на іншому - більш загальний підхід, що розглядає проблему об'єкт-суб'єктних взаємин (між людиною і предметом). Фактично ми маємо справу із різними рівнями абстрагування в рамках однієї системи взаємопов'язаних параметрів", і не можна стверджувати, що лише один з них $\epsilon$ правильним і спростовує всі інші ${ }^{13}$.

Спробуємо тут дати детальнішу характеристику основним з окреслених вище підходів.

Серед них до числа найпоширеніших належить інституційний ${ }^{14}$. У його рамках музей розглядається як соціокультурний інститут, що має певну структуру та виконує низку функцій. Різні дослідники віддають при цьому перевагу відмінним варіянтам бачення того, який саме набір функцій $є$ визначальний, основним для музею. Власне музей розглядається як, насамперед, науково-дослідна установа; культурно-освітня установа; освітня установа; рекреаційна установа ${ }^{15}$.

Не заперечуючи вагомости аргументів на користь погляду на музей як на соціяльний інститут, критики інституційного підходу, проте, акцентують увагу на його слабких моментах, вказують на його однобічність, недостатність, невиправданість “редукування" феномену музею до лише одного з його проявів. Зокрема, зауважують, що названі вище функції виконують і низка інших соціяльних інститутів, тому розуміння музею лише через їх призму не може бути задовільним ${ }^{16}$.

Альтернативою інституційному підходові постає предметний. Дослідники, що спираються на нього, стрижнем свого аналізу музею та розуміння музеєлогії як наукової дисципліни роблять категорію музейного предмету. Так, східнонімецький музейолог К. Шрайнер визначає музеєзнавство як науку про збирання, збереження, вивчення і використання музейних об'єктів; відповідно, ііі предметом визнають суспільна діяльність, що реалізують у формі музейної роботи ${ }^{17}$.

У рамках предметного підходу окреслювала зміст музеєзнавства німецька дослідниця В. Ян, яка вказувала, що сутність музейництва пов'язана 3 пізнавальною діяльністю суспільства та музейними предметами - джерелами

\footnotetext{
12 Петер ван Менш, “Предмет музеологии”, Вопросы музеологии, № 1 (9), (2014): 66.

${ }^{13}$ Ibidem.

14 Е. Смыкова, “Теоретико-методологические подходы к изучению музея как социокультурного феномена", Социально-гуманитарный вестник Прикаспия: научный журнал, № 1 (2), (2015): 27.

${ }^{15}$ Ibidem, 27-30.

${ }^{16}$ Ibidem, 30.

${ }^{17}$ Клаус Шрайнер, “Предмет исследования музееведения и происхождение дисциплины”, Музееведение. Музеи мира. Сб. науч. трудов НИИ культуры. (1991): 47.
} 
інформації, і процедурою перетворення звичайних речей у музейні предмети ${ }^{18}$. Німецький музейолог В. Еппенбах визначав предмет музеєзнавства як “дослідження структури відносин: людина - музей - музеяліі”; тут музеялії це матеріяльні предмети, що мають потенційну або реалізовану засобами музеялізації музейну цінність ${ }^{19}$. Йдеться не про предмети як такі, їх дослідження у рамках методології численних конкретних дисциплін, із ними пов'язаних, а про функцію предметів бути носіями певної інформації, мати соціокультурну вартість, яку суспільство сприймає, реалізує специфічними музейними засобами.

Розвиваючи цей підхід, український музеєзнавець Ю.Омельченко проводив розрізнення між “предметом музейного значення" (ПМЗ) та “музейним предметом" (МП). ПМЗ для нього - це річ, "що має потенційну музейну цінність, але не долучена до складу музейного зібрання. ...Йдеться про ту частину предметного світу, яка побутує в оточуючому середовищі і оновленою музеєлогією наділяється “музеяльністю" - властивістю речей бути специфічним засобом забезпечення культурної наступности, передачі соціяльного досвіду”20.

У цьому зв'язку Ю. Омельченко висловив погляд, що в сучасному музеєзнавстві проблема генези предмету музейного значення та його переростання в музейний предмет майже не розглядається. Розробка ж теорії музейного предмету (за термінологією названого автора, першої підсистеми музейництва) має спиратися на те, що дослідник називав “культурологічним тлумаченням понять “предмет" та "річ". Ю.Омельченко покликається на концепцію російського культуролога М. Епштейна, для якого різниця між предметом та річчю - це різниця між світом об'єктів та світом суб'єктів. Для М. Епштейна “предмет - лише потенційна можливість речі, іiі субстрат. Предмет перетворюється на річ в міру духовного освоєння, так само як індивідуальність перетворюється в особистість у процесі свого самоусвідомлення, самовиз-начення, напруженого саморозвитку"21. Тут, на наш погляд, присутня виразна аналогія між процесом трансформації об 'єкта - предмета - у суб 'єкm - річ та процесом музеєзації - набуття тими чи іншими предметами специфічної музейної вартости.

Критикуючи чисто інституційний або предметний підхід, львівський музеєзнавець О. Климишин зауважив: “Ці два підходи обтяжені тим уявленням, що предмет музеєлогії мусить бути пов'язаний із музеєм або музейною діяльністю. Проте очевидно, що музей у цьому контексті не $є$ метою, а лише засобом пізнання" 22 .

${ }^{18}$ Юрій Омельченко, “Перша підсистема музейництва (теоретичні засади, витоки, формування)”, Культурологічні студії. Збірник наукових праць, Вип. 2, (1999): 289. На жаль, дослідниквживаєзросійщенийтермін “музеоогія”.

${ }^{19}$ Ibidem.

${ }^{20}$ Юрій Омельченко, “Перша підсистема музейництва (теоретичні засади, витоки, формування)”, Культурологічні студії. Збірник наукових прачь, Вип. 2, (1999): 293.

${ }^{21}$ Ibidem, 292.

22 Олександр Климишин, “Сучасні проблеми природничої музеології”, Наукові записки Державного природознавчого музею, Вип. 26, (2010): 4. 
ISSN 2078-6077. Наукові зошити історичного факультету Львівського університету. 2018-2019. Випуск 19-20. Proceedings of History Faculty of Lviv University. 2018-2019. Issue 19-20.

У 1960-ті рр. виникла та набула впливу концепція “музейної комунікації”, що на якийсь час опинилася в центрі теоретичних побудов музеєзнавців. Ї̈̈ автором був канадський музейолог Д. Кемерон, який застосував до аналізу діяльности музеїв теорію комунікації американця К. Шеннона. Д. Кемерон визначив музей як комунікаційну систему, що охоплює канали візуяльної та вербальної інформації. Обмін вербальною інформацією може мати і односпрямований, і двобічний, діялогічний характер ${ }^{23}$. Результат процесу музейної комунікації залежить від здатности відвідувачів сприймати “мову речей”, і від здатности творців експозиційного простору виразити свої ідеї мовою предметів ${ }^{24}$.

Згодом важливий внесок у вдосконалення теорії музейної комунікації зробили англійський музеєзнавець Е. Купер-Грінгілл, канадський культуролог М. МакЛюен. У подальшому розвиток комунікаційної моделі відбувався вже у рамках семіотичного підходу, за якого музейна комунікація розглядається як своєрідна знакова система. Зокрема, він представлений у роботах російського музеєзнавця В. Арзамасцева, української дослідниці Н. Буланової ${ }^{25}$.

Важливою віхою в дискусії про предмет та методи музеєлогії стали, починаючи від 1960-х рр., роботи чеського музейолога Збинека Странскі. На його думку, щоб дати відповідь на питання - у чому ж предмет музеєлогії, слід усвідомити, що музей не є метою, але тільки засобом. "Музейні установи, підкреслював він, - історично виникають і розвиваються як засоби для реалізації специфічного ставлення до дійсности. Специфічність цього ставлення полягає у тому, що людина зі свого оточення відбирає предмети, які для неї репрезентують певні культурні вартості. Ці репрезентанти вона зберігає, щоб використати їх в новому контексті як культуротворчі чинники"26. Отже, твориться “уречевлена пам'ять”, “яка служить історичній свідомості і заодно є виразом існуючої культури". Для визначення такого специфічного ставлення до дійсности 3. Странскі запропоновував термін “музеяльність”; те, що репрезентує це ставлення - музеялії. Відтак музеєлогія, за його висновком, повинна дати змогу пізнати, що є музеяльним, а що ні, і якими засобами цю музеяльність можна реалізувати.

${ }^{23}$ Е. Смыкова, “Теоретико-методологические подходы к изучению музея как социокультурного феномена”, Социально-гуманитарный вестник Прикаспия: научный журнал, № 1 (2), (2015): 32 .

${ }^{24}$ Ibidem.

${ }^{25}$ Валентин Арзамасцев, “О семантической структуре музейной экспозиции”, Музееведение. На пути к музею XXI века: Сб. науч. трудов, (М., 1989): 35-49.; Наталія Буланова, “Семантика музейного предмета (на основі етнографічної колекції Музею історії м. Дніпродзержинськ)”, Музей на межі тисячоліть: Минуле, сьогодення, перспективи. Збірник тез, доповідей $і$ повідомлень міжнародної наукової конференції, присвяченої 150-літтю з дня заснування Дніпропетровського історичного музею ім. Д. Яворницького, (Дніпропетровськ, 1999): 49-50.

${ }_{26}^{2}$ Збінек Странскі, “Теоретичні засади музеології як науки”, Доп. на міжнародному симпозіумі "Музеологія. Нові иляхи - нові ичілі" національних комітетів ІКОМ ФРН, Австрії і Швейцарії в Бадензее, Швейцарія, 11-14 травня 1988 р. Матеріали симпозіуму: 39-47. Пер. 3 нім. 3. Мазурика отримано доступ 10 травня 2018: http : // prostir.museum/ua/post/27922 
Ідею 3. Странскі піддали критиці, проте вона стала однією з найвпливовіших у музеєлогії, і в подальшому іï розробляли також інші теоретики. Ї̈і, зокрема, по суті приймає австрійський музейолог Фридрих Вайдахер, у своєму відомому посібнику з музеєлогії. Для нього музеєлогія - це “здійснене за допомогою філософських інструментів теоретичне пояснення та практичне застосування особливого пізнавального і оцінювального ставлення людини до своєї дійсности. Це ставлення називається музеяльністю. Своє конкретне вираження вона знаходить у предметах, що відбирають, зберігають, досліджують та використовують на службу суспільства як свідчення певної суспільної дійсности" 27.

Як і 3. Странскі, музеяльність предметом вивчення музеєлогії вважав хорватський музейолог Іво Мароєвич. Він пояснював властивість предметів бути носіями музеяльности так: “....музеяльність $є$ характеристикою чогось, що в одній реальності документує іншу, у сучасному воно $є$ документом минулого, у музеї документом реального світу, усередині одного простору документом інших просторових зв'язків" ${ }^{28}$.

Об'єкт, що є носієм музеяльности, стає музеялією. “Його характеристикою $\epsilon$ те, що у відмінну музейну реальність він впроваджений (узятий) для того, щоб документувати реальність, до якої він початково належав, яка відрізняється за місцем, часом та суспільством, так що річ може відтак розглядатися як така, що документує місце, час або суспільство" 29 . І. Мароєвич вказував, що музеяльність “ $є$ найочевиднішою в об'єктах, які музеялізовано, або ж у середовищі, яке повністю або частково музеялізовано, у сенсі активної комунікації та інтерпретації його документаційної або іншої вартости"зо.

Крім предметів у музеях, музеяльність $є$ властивістю таких, наприклад, об'єктів, як церкви, замки (законсервовані та відкриті для публіки), місць археологічних розкопок, руїн, історичних міст, що мають певні інтерпретаційні знаки, музеїв просто неба, ботанічних садів і т.ін. Але "музеяльність присутня також у буденних предметах, в яких люди можуть знайти зв' язок з фрагментами минулого та місць, які було збережено; і кожному, кому вдається встановити змістовний контакт із ними, вони розповідають про суспільство, 3 якого початково походять, про людей місця та часу походження"31. Тобто музеяльність властива не лише музейним предметам чи музеєфікованим об'єктам.

У ширшому контексті, для I. Мароєвича у тлумаченні “музеяльности” йшлося про поняття “спадщини”. Він писав, що “....зникнення об’єктів не означає

${ }^{27}$ Фридрих Вайдахер, “Загальна музеологія”, (Львів, 2005): 34.

${ }^{28}$ I. Maroević, "Museology as a discipline of informational science", Nordisk museologi, No. 2, (1997): 83. отримано доступ 20 серпня 2018: http : // www.journals.uio.no/index.php/museolog/.../ 3105.

${ }^{29}$ Ibidem.

${ }^{30}$ Ibidem, 84.

31 Ibidem. 
ISSN 2078-6077. Наукові зошити історичного факультету Львівського університету. 2018-2019. Випуск 19-20. Proceedings of History Faculty of Lviv University. 2018-2019. Issue 19-20.

зникнення нашого знання про них. Акт набуття ними музеяльности є, фактично, початком їх порятунку від небуття. Це $є$ однією 3 перших функцій музеїв та цілої роботи із захисту культурної та природної спадщини”з2.

Спираючись на концепт музеяльности, І.Мароєвич зміст музеєлогії визначив так: “Предметом музеєлогії є дослідження характеристик об'єктів чи комплексів культурної спадщини, які можуть, у певним чином організований та спрямований спосіб, передавати інформацію від людей до людей і суспільства, від одного часу до іншого, в рамках різних контекстів, насамперед археологічному і музейному, і про шляхи та історію шляхів організації і передачі такої інформації’’з3 .

На його думку, цю інформацію можна розділити на два типи: наукову та культурну. Наукова пов'язані із науковими фактами, а культурна - з тією цінністю, що атрибутують предмет у соціяльному контексті. Науковою інформацією займаються відповідні профільні дисципліни, музеєлогію ж цікавить культурна інформація ${ }^{34}$.

Ілюстрацією цієї думки, на наш погляд, міг би бути такий приклад. Якщо в сучасному українському музеї зберігається та експонується, приміром, гвинтівка українського січового стрільця, то пов'язана із нею наукова інформація технології, військова тактика, історія бойового використання та ін. - вивчають наукові дисципліни відповідного профілю. Предметом вивчення музеєлогії натомість має бути той соціокультурний контекст, в якому ця стара гвинтівка стає певною цінністю, і увесь проиес/механізм ії музеєзації - потрапляння до музею, його сховища, в реставраційні майстерні, постійну експозицію, на тимчасові виставки, пояснення ії значення екскурсоводами і т. д. Водночас, в іншому контексті вона могла б бути лише непотрібним іржавим предметом, придатним хіба що на металобрухт.

Використовуючи у своїх роздумах концепцію “музеяльности" 35 власне бачення окремих iï вимірів запропонувала О. Сапанжа. Дослідник констатувала, що “оформлення та розвиток музеслогії підтвердило можливість різнобічного вивчення феноменів виявів “музейности”. 3 іншого боку, становлення і розвиток музеслогії як самостійної науки не виключає міждисциплінарного підходу щоб визначити місце і роль музею в сучасній культурі. Особливе місце, визначаючи міждисциплінарні зв'язки музеєзнавства відводять культурології і саме ії методологічні настанови розглядають як продуктивні при аналізі природи та сутности музею"з6.

32 I. Maroević, "Museology as a discipline of informational science", Nordisk museologi, No. 2, (1997): 83. отримано доступ 20 серпня 2018: http : // www.journals.uio.no/index.php/museolog/.../ 3105. 83 .

${ }^{33}$ Ibidem, 84-85.

${ }^{34}$ Петер ван Менш, “Предмет музеології, Вопросы музеологии, № 1 (9), (2014): 69.

${ }^{35}$ В усталеному російському варіянті передачі терміну 3. Странскі - “музейности”; вважаємо можливим тут і далі використовувати при перекладі російського тексту як український відповідник термін “музейність”, як синонім запропонованого 3. Мазуриком терміну “музеяльність".

${ }^{36}$ Ольга Сапанжа, “Культурологическое измерение музея: морфология музейности”, Bonpocbl музеологии, № 2 (4), (2011): 5. 
Розмірковуючи над концепцією 3. Странскі, російська дослідниця розклала низку власних акцентів. Музей $є$ найлогічнішим виразом суспільного прагнення зафіксувати сучасність та "прокоментувати" минуле. Разом із цим, існують й інші, не музейні форми реалізувати це прагнення, чи цю потребу - тобто “музейність" (музеяльність). Проте музейність зосереджена не лише у музеях та музейних предметах. Запроваджуючи поняття "музеялій”, 3. Странскі, за заувагою О. Сапанжі, переносить фокус у виявленні сутности музейности 3 інституту на власне ці музеялії. Дослідниця пропонує своє бачення їхньої сутности, сформульоване так: “Най точнішим при характеристиці поняття “музеялії” видається звернення до поняття “культурний артефакт”. ...Якщо музей $\epsilon$ культурною формою (а різні напрямки не музейного вираження музейности іiі варіянтне відтворення), то структурування музеялій (носіїв музейности) в рамках конкретного музею, приватної збірки і т. ін. можна розглядати як культурні артефакти".

У рамках своєї концепції диференціяції музейного знання О. Сапанжа сформулювала власну дефініцію змісту музеєлогії. Дослідниця виходить із засади про три напрямки музейних/музеєзнавчих студій. На найвищому з них йдеться про пошук концептуальних основ, насамперед теоретичних, на які, як на методологічні базу науки, мають спиратися практичні дослідження ${ }^{37}$. Другий напрямок заснований на використанні методів, що застосовують в історичних та практичних музеєзнавчих дослідженнях. Зміст третього складають, за визначенням О. Сапанжі, технології музейної роботи.

Виходячи 3 такого бачення загальної структури музеєзнавчих досліджень, О. Сапанжа визначає три відповідні рівні музейного знання: концептуальний (найвищий), синтетичний, технологічний. Спираючись на це розмежування, дослідниця сформулювала і своє визначення музеєлогії, музеєзнавства та музейної справи.

Відтак зміст музеєлогії, за О. Сапанжею, становлять теоретичні дослідження, підсумком яких має стати створення і розвиток наукових теорій; іншими словами, це - спеціяльна теорія музея і музейности, яка репрезентує концептуальний рівень студій. Натомість музеєзнавство - культурологічна наука, що дозволяє "підсумувати різноманітні знання з різних аспектів історії, теорії і практики музейної справи", або дослідження синтетичного характеру, орієнтовані на міждисциплінарний підхід ${ }^{38}$. Музейна ж справа відповідає технологічному рівневі, і є сукупністю технологій (музейно-педагогічних, фондової роботи і т. ін.), що забезпечують функціонування музейних інститутів і сприяють вирішувати конкретні практичні завданя музейної роботи. (Поняття ж “музейографії”

\footnotetext{
${ }^{37}$ Ольга Сапанжа, "Историография музеологии, музееведения, музеографии. К вопросу разделения понятий”, Вопросы музеологии, № 2 (8), (2013): 199.

${ }^{38}$ Ольга Сапанжа, "Историография музеологии, музееведения, музеографии. К вопросу разделения понятий”, Вопросы музеологии, № 2 (8), (2013): 201.
} 
ISSN 2078-6077. Наукові зошити історичного факультету Львівського університету. 2018-2019. Випуск 19-20. Proceedings of History Faculty of Lviv University. 2018-2019. Issue 19-20.

позначає опис музеїв, їх експозицій та колекцій, і належить до синтетичного рівня музейного знання, тяжіючи до музеєзнавства).

Спробу обгрунтувати власне оригінальне бачення змісту музеєлогії, зробив українець П. Усенко. В основу його роздумів покладено ідеї, які розвивав у своїй роботі “Археологія знання” (1969) відомий французький філософ Мішель Фуко. Ключові засади концепції вітчизняного дослідника сформульовано так.

"Музеєлогія, - стверджує П. Усенко, - стала можливою, тому що став можливим перехід від вивчення музеїв, музейних предметів і суспільства в їх постійній взаємодії до структур уже сформованого і втіленого в музейологічних практиках музеєлогічного знання. Музеєлогія повинна, передусім, виявити той розрив, який зробив іiі можливим"з9. У своїх роздумах дослідник використав поняття “музеєзації”: “...якщо ми уявимо, що “музеєзація” - моделювання реальности минулого чи сучасного засобами музейних практик $<\ldots$. , то музеєлогія вивчає і узагальнює досвід музеєзації. Відтак музеєлогія має займатися “ідеологією музею”, який практикує порядки розміщення предметів у просторі, пропонує контексти і взаємозв'язки, бере участь у встановленні преференцій, на основі яких здійснють відбір і вивчення матеріялу, формують мистецький смак, відбувається інвентаризація і оцінювання тих чи інших пам'яток культури" "40.

Усупереч загалом прийнятому в Україні ототожненню цих понять ${ }^{41}$, П. Усенко пропонує розрізняти музеєзнавство (стаття надрукована російською мовою, тому в оригіналі - “музееведение”; автор при цьому подає англійський відповідник, яким він вважає словосполучення “museum studies”) та музеєлогію (“museology”). Музеєзнавство вивчає те, яким способом музеї роблять з пам'ятки документ; натомість музеєлогія - “експліковану документальність”.

За П. Усенком, музеєлогія “розкриває зв”язок між дискурсивною формацією, як реальністю, що творить закон (розуміння “музейности” у конкретну епоху), $\mathrm{i}$ недискурсивною областю (наприклад, музейний предмет, експозиція)"42. "Кажучи просто, музеєлогія повинна займатися музейним дискурсом", резюмує автор ${ }^{43}$.

Свої роздуми П. Усенко підсумував так: “Оскільки музеєлогія виникає на основі цілої системи висловлювань і стосунків, які утворюються разом із інтеграцією музейних практик у соціяльно-економічний, політичний, літературнохудожній та інші контексти (якщо ми говоримо про музей як про систему

\footnotetext{
${ }^{39}$ Павло Усенко, “Музеология - наука, дисциплинарный образ или совокупность вербальных форм?”, Вісник Дніпропетровського університету. Серія історія та археологія, Вип. 18, (2010): 297.

${ }^{40}$ Ibidem, 297-298.

${ }^{41}$ Руслана Маньковська, “Музеологія як наукова галузь: сучасний дискурс та проблема науковго інтегрування”, Краєзнавство, № 3-4, (2009): 138.

42 Руслана Маньковська, “Музеологія як наукова галузь: сучасний дискурс та проблема науковго інтегрування”, Краєзнавство, № 3-4, (2009): 298.

${ }^{43}$ Ibidem.
} 
музейних практик), то $є$ очевидною і культурологічна широта кола можливих дослідницьких джерел. До їх числа можуть входити наукові праці прикладного характеру, юридичні норми, що інтегрують музей у систему суспільних взаємин, літературні тексти, внутрішньомузейна документація зі зберігання, обліку і класифікації фондів та ін. Словом, цілий масив вербальних висловлювань, який дає нам можливість говорити про формування дисциплінарного образу музеєлогії в контексті сучасної гуманітаристики. При цьому “образність дозволяє ухилитися від строгих академічних форм в репрезентації об'єкта дослідження, а дисциплінарна форма є обов’язком досліджувати і контролювати невпорядковану спонтанність дискурсивних практик"

Отже, відповідь автора на поставлене в заголовку питання полягає в тому, що музеєлогія повинна займатися музейним дискурсом, а іiі зміст становить саме певна сукупність вербальних форм. На наш погляд, стаття П. Усенка $\epsilon$ спробою дати музеєлогії дефініцію в рамках радше суто філософського, ніж усталеного музеєзнавчого дискурсу, а тлумачення, що він пропонує, веде до “розчинення" іiі предмету у “масиві вербальних висловлювань”, в якому межі дисципліни надто розмиваються, якщо не втрачаються.

Пошук відповіді на питання про предмет та зміст музеєлогії спонукає дослідників звернутися до проблеми визначення іiї методології. За зауваженням О. Сапанжі, “... під час осмислення музею як феномену, спробі цілісного аналізу багатоликого....музейного простору метод стає наріжним каменем дослідження, його відправною точкою, без якої є неможливим сам процес комплексного аналізу цього простору"45.

У ході методологічної дискусії чималий вплив здобула концепція чеського музейолога Іржі Неуступни. Він був автором першого в Европі підручника 3 музеєлогії, який побачив світ у 1950 p. ${ }^{46}$ У ньому він визначав музеєлогію як прикладну науку, називаючи іiі об'єктом музейництво (музейну роботу), а предметом - музей як суспільне явище.

У своїх пізніших публікаціях І. Неуступни аргументував точку зору, що музеєзнавство по суті є сумою методів профільних дисциплін, “синтезом спеціяльних музеєлогій”, застосуванням конкретної науки до діяльности музею. Власного методу музеєзнавство не має, але повинно запозичати методи з інших дисциплін, застосовуючи їх розв'язувати ті чи інші конкретні дослідницькі зав дання ${ }^{47}$.

\footnotetext{
${ }^{44}$ Руслана Маньковська, “Музеологія як наукова галузь: сучасний дискурс та проблема науковго інтегрування”, Краєзнавство, № 3-4, (2009): 298-299.

${ }^{45}$ Ольга Сапанжа, “Современное теоретическое музееведение: к вопросу методологи науки": 1-6. отримано доступ 20 серпня $2018 \mathrm{http}$ : // www.cyberleninka.ru/article/n/sovremennoe...

${ }^{46}$ Дмитро Кепін, “Внесок І. Неуступного до розвитку музеології”, Праці Центру пам'яткознавства, № 17, (2010): 180.

${ }^{47}$ Ibidem.
} 
ISSN 2078-6077. Наукові зошити історичного факультету Львівського університету. 2018-2019. Випуск 19-20. Proceedings of History Faculty of Lviv University. 2018-2019. Issue 19-20.

Досить радикально позицію тих, хто заперечував можливість існування у музеєлогії власного специфічного пізнавального методу висловив американський музейник Вілкомб Е. Вошборн, у статті з іронічною назвою, яку можна перекласти як “Бабцялогія та музеєлогія" 48 . Він “відкинув саму ідею можливости чи необхідности створення особливої музейної професії, стверджуючи, що музейна робота не має власної незалежної ідентичності - вона розвивається 3 профільних дисциплін ${ }^{49}$.

Одним з головних опонентів “скептиків” був 3. Странскі, який вважав, що музеєлогія, хоча вона “у процесі пізнання і оцінювання [...] спирається на внесок наукових галузей, які вивчають ту частину реальности, яка стає предметом “музеєції”, здатна і повинна створити власну методологію.

Музеєлогія, за 3. Странскі, досі оперує "загальними і переважно запозиченими методами", проте "чим далі будуть заглиблюватися власні гносеологічні зусилля музеєлогії, тим більше буде розвиватися і ії методична база". "Систематизація музейологічної термінології поза рамками власного теоретичного дозрівання музеєлогії видається неможливою", - наголосив він.

3. Странскі виділяв три стадії процесу формування музеєлогією власної методології: донаукову, емпірично-описову, теоретико-синтетичну. Чеський дослідник зробив спробу систематизувати музеєлогію за сутністю предмету пізнання. Запропонований ним структурний поділ виглядає так:

- історична музеєлогія;

- теоретична музеєлогія:

1. теорія музейної селекції;

2. теорія музейного тезаврування;

3. теорія музейної комунікації.

- прикладна музеєлогія.

При цьому, за 3. Странскі, через “стосунки” музеєлогії з іншими дисциплінами постають “спеціяльні музеслогії” (інтердисципліни). Такий варіянт систематизації був підтриманий багатьма фахівцями, зокрема, він прийнятий авторами музеєологічного підручника, який підготував колектив авторів з (колишніх) НДР та $\mathrm{CPCP}^{50}$.

В останні роки нових вимірів дискусії про предмет та методи музеоєлогії додає все більше розширення та ускладнення форм діяльности та інституційних форм, які сприймаються як музейні. На це, зокрема, вказувала О. Сапанжа, яка писала, що, наприклад, поширена методологія вивчення музею як соціокультурної інституції виявляється неефективною, оскільки “визнаний нині предмет науки музейність - з усією впевненістю вказував на розширені рамки пошуку втілення цієї “музейности”, а сам музей у цьому контексті став лише найяскравішою,

\footnotetext{
${ }^{48}$ W.E. Washborn, "Grandmotherology and museology", Curator, No. 10(1), (1967): 43-48.

49 Петер ван Менш, “Дискурс музеологии”, Вопросы музеологии, № 1 (9), (2014): 27.

${ }^{50}$ Музееведение. Музеи исторического профиля. Уч. пос. для вузов. (Москва, 1988).
} 
типовою формою ії прояву - типовою, але не єдиною" 51 . Успішне застосування у дослідженнях, так чи інакше пов'язаних із музеями та музейною практикою, різноманітних методів відмінних профільних наук, приміром, історії в історичному музеєзнавстві або методів природничих наук, за словами дослідниці, “не дозволяє назвати музеєзнавство самостійною наукою, а не практичною сферою чи окремим напрямком інших наук” (тобто, не є достатнім аргументом для цього) ${ }^{52}$.

О. Сапанжа висловила погляд, що “точкою відліку” у пошуку фундаментальної основи для музеєлогічної теорії стала, у 1980-ті-1990-ті рр., "культурологічна система координат" 33 . Саме в рамках цієї системи дослідниця намагається сформулювати власний підхід до проблеми методології музеєзнавства. У той час, як у прикладному музеєзнавстві стверджувався інтердисциплінарний підхід, підкреслила О. Сапанжа, “розвиток[...]теорії культури визначив звернення музеєзнавців до фундаментальних основ культурологічного знання і поклав початок культурологічного підходу у музеєзнавстві”.

О. Сапанжа наголосила на проблемі створення типології сучасного музейного простору, органічно пов'язаною з проблемою методології музеєзнавства. Цей простір сьогодні є дуже багатовимірний, поліморфний та строкатий; водночас, саме культурний вимір, належність до простору культури є тим, що єднає усі надто відмінні форми музейної практики. Відтак у пошуках відповіді на питання про належність тих чи інших культурних практик до "музею" чи "не музею" логічно звертатися до культурології ${ }^{5}$.

У рамках культурологічного підходу російський дослідник М. Каган застосував (у тому числі) до музею поняття “культурної форми", як моделі цілісної культури, що відтворюється на окремій ділянці ії цілого спектру55. Розвиваючи ідею М. Кагана, російський теоретик музеєлогії Т. Калугіна тлумачить музей як одну з підсистем “етасистеми” культури, а виникнення музею - як результат "музейного" ставлення до дійсности, намагання людини втримати безкінечне багатство та різноманітність світу ${ }^{56}$.

За О. Сапанжею, “визнання музею “культурною формою” і залучення музеєзнавчої проблематики до кола теоретичних культурологічних досліджень мали визначити і систему методологічних координат науки"57. На їі думку, саме 3 культурологічним підходом най повніше кореспондують гносеологічний та

\footnotetext{
${ }^{51}$ Ольга Сапанжа, “Современное теоретическое музееведение: к вопросу методологи науки”: 1-6. доступ отримано 20 серпня 2018: http : // www.cyberleninka.ru/article/n/sovremennoe...

${ }^{52}$ Ibidem, 2-6.

${ }^{53}$ Ibidem, 4-6.

${ }^{54}$ Ольга Сапанжа, “Культурологическое измерение музея: морфология музейности”, Bonpocbl музеологии, № 2 (4), (2011): 7.

${ }^{55}$ Ibidem, 5-6.

${ }^{56}$ Т. Калугина, “Художественний музей как феномен культуры”, (Санкт-Петербург, 2001): $14-15$.

${ }^{57}$ Ольга Сапанжа, “Современное теоретическое музееведение: к вопросу методологи науки”: 6-6. отримано доступ 20 серпня 2018, http : // www.cyberleninka.ru/article/n/sovremennoe...
} 
ISSN 2078-6077. Наукові зошити історичного факультету Львівського університету. 2018-2019. Випуск 19-20. Proceedings of History Faculty of Lviv University. 2018-2019. Issue 19-20.

аксіологічний аспекти музейної науки, що їх проголосив 3. Странскі. Дослідниця вважає, що “опора на культурологічний підхід у сполученні з трьома чинними складовими теоретичного музеєзнавства (теорією документування, тезаврування та комунікації) "може бути основою для напрацювання оригінальних методів теоретичного музеєзнавства". За їі припущенням, такими методами могли б бути, відповідно до названих “секторів музейної теорії, музейно-документаційний метод, музейно-аксіологічний метод та метод музейно-комунікаційного аналізу. Їх розвиток, змістовну реалізацію у застосування до тих чи інших дослідницьких завдань О. Сапанжа вважає справою майбутнього.

Суголосно 3 О. Сапанжею, Л. Шляхтина у своій теоретичній розвідці акцентувала на постійному розширенні форм музейної практики, меж музейного світу. "Рамковим" виміром цього розширення вона бачить глобалізацію, яка "залучає національні культури у якісно нову світову єдність, що за своєю природою $\epsilon$ транснаціональною" 58 .

Разом із цим, набувають все більшого поширення нові, нетрадиційні форми музейної діяльности. Дослідниця вказує, зокрема, на явище “м'якої музеєфікації”, “коли значні території, особливо багаті пам'ятками, зберігають і демонструють у вигляді “археологічних" i “етнографічних зон” 59 . У містах створюють “музейні квартали”, у яких зберігають та реконструюють історичне середовище. Варіянтом “м'якої музеєфікації” природного середовища $\epsilon$ природоохоронні установи. Поширеними типом музейної інституції стають заклади, створені через з'єднання музею з іншою установою - школа-музей, музей-театр, бібліотекамузей, навіть (у російському м. Слабуга) Музей-трактир-театр, і т. ін. ${ }^{60}$

У 1970-ті рр. у Европі з'явилася така “гібридна” форма музейної діяльности, як “екомузей” - тип музею, спрямований вирішувати соціяльно-економічні чи культурні проблеми місцевого населення шляхом його активного залучення у роботу зі збереження і використання усіх форм місцевої спадщини. Ще одним різновидом музейного закладу стали сьогодні “економузеі”” - установи, що функціонують на основі об'єднання музеїв і невеликих майстерень, діяльність яких базується на творчому використанні народних традицій. Новацією сучасного музейного простору є “брендові музеї”, в основі яких лежить певний образ, ідея, які привертають відвідувачів ${ }^{61}$.

Констатуючи складність актуального "наукового ландшафту музеєлогії", Л. Шляхтіна визнала за можливе заявити про ії “методологічну інфантильність”. Свою версію способу подолати такий стан справ дослідниця сформулювала так: “Можна припустити, що теоретичні уявлення синергетичного світобачення

\footnotetext{
${ }^{58}$ Ibidem, 2-6.

59 Людмила Шляхтина, “Современная музеология: горизонты теоретизирования”, Bопросы музеологии, № 1 (7), (2013): 12.

${ }^{60}$ Ibidem, 15.

${ }^{61}$ Людмила Шляхтина, “Современная музеология: горизонты теоретизирования”, Bonpocbl музеологии, № 1 (7), (2013): 15.
} 
(бачення світу як системи, здатної до самоорганізації або самодезорганізації. B.К.,T.M.) можливі як нова наукова парадигма, що дозволяє пояснити народження складного явища, а також зрозуміти процеси морфогенезу музейного світу”62. Підсумовуючи сказане у статті, наголосимо таке. Попри міцний академічний статус музеєлогії, в науковому середовищі не існує консенсусу щодо iii змісту та методології. Най радикальнішого, і водночас вельми поширеною $\epsilon$ точка зору, що музеєлогія в остаточній редукції є сукупністю інших численних дисциплін, методи яких вона і повинна застосовувати щодо свого специфічного предмету.

Водночас і цей предмет визначають дуже по різному. Найбільшим впливом користується концепція “музеяльности”, яка постає ядром аналітичних роздумів багатьох музейологів. Разом із цим, набув поширення погляд на музеєлогію як на культурологічну дисципліну. I якщо частина дослідників взагалі заперечує можливість існування специфічно музеєлогічної дослідницької методології, то інші вважають, що триває процес іï формування, втім, утримуючись при цьому від точних формулювань.

\title{
THE PROBLEM OF THE SUBJECT AND METHODS OF MUSEOLOGY IN MODERN MUSEOLOGICAL DISCOURSE: BASIC APPROACHES AND ALTERNATIVE VIEWS
}

\author{
Vitaliy KUSHNIR \\ National Academy of Science, \\ The Institute of Ethnology \\ Svobody prospect, 15, 79000, Lviv, Ukraine \\ e-mail: vitaliy_val@ukr.net \\ Taras MARYSKEVYSH \\ Ivan Franko National University of Lviv, \\ Department of Local History \\ Universytetska str., 1, 79000, Lviv, Ukraine \\ e-mail: kf.kraeznavstva@gmail.com
}

Today, there is a wide range of differences in the views of researchers on the problem of determining the subject of museology.

In order to outline the current state of affairs in theoretical museology, the influential Dutch museologist Peter van Mensh has used a definition - "conceptual and methodological chaos". It is possible to single out the most influential points of view, some of the most notable currents in the museological theorizing. Today, the basis of a wide range of research understanding of the basic content of museology is formed by several alternative approaches. Although they developed at different times, the formation of new foundations of the vision of museum study did not lead, however, to the complete

\footnotetext{
62 Людмила Шляхтина, “Современная музеология: горизонты теоретизирования”, Bonpocbl музеологии, № 1 (7), (2013): 15.

${ }^{63}$ Ibidem.
} 
ISSN 2078-6077. Наукові зошити історичного факультету Львівського університету. 2018-2019. Випуск 19-20. Proceedings of History Faculty of Lviv University. 2018-2019. Issue 19-20.

"elimination of other concepts, It predetermined the expansion and complication of the theoretical toolkit of museology. According to each of them, researchers in different ways substantiate their understanding of the basic subject of museology.

The most influential approaches now are institutional, objective and complex. The first understands museology as a study of museum institutions; the second - as a study of museum objects, and the third - as a study of museums. In the 1960's, the concept of "museum communication" came into being and became influential. It was promoted by Canadian musicologist Cameron, who used Shannon's theory of communication to analyze the work of museums. Cameron defined the museum as a communication system that includes visual and verbal information channels.

Since the 1960's an important milestone in the discussion of the subject and methods of museology has been, the works of the Czech museologist Zbinek Stranky. He believed that museum institutions are historically emerging and developing as a means of implementation a specific attitude to reality. The specificity of this attitude is that a person in friendly environment selects items that represent certain cultural values. To determine such a specific attitude to the reality Stransky proposed the term "museality". Therefore, according to his conclusion, the museology should be able to know what is "museal", and what is not, and by what means this museality can be implemented.

The tries to find the answer to the question about the subject and content of museology encourage researchers to address the problem of defining its methodology. Some researchers deny the possibility of the existence of specific cognitive method of museology, believing that it is a complex discipline.

Despite the strong academic status of museology, there is no consensus on the problem of it content and methodology in the scientific community. The most radical and at the same time widespread is the point of view that muzeology ultimately represents a set of other numerous disciplines, the methods of which should be applied to its specific subject.

The concept of "museality", which appears to be the core of the analytical reflections of many museologists, now has the greatest influence. At the same time, the view of museology as a culturological discipline became widespread. And if some researchers deny the possibility of the existence of a specifically museological research methodology, then others believe that the process of its formation continues, however, while refraining from accurate formulations.

Key words: museology, museum objects, the subject of museology.

\section{REFERENCES}

Arzamastsev, V. "On the semantic structure of the museum exposition", in Museology. On the way to the museum of XXI century, Moscow, 1989, 35-49. (in Russian)

Bulanova, Natalia "The semantic of the museum object (basing on the ethnography collection of the History museum of Dniprodzerzhynsk)", in Museum at the brink of millenium: past,contemporary, perspectives, Dnipropetrovsk, (1999): 49-50. (in Ukrainian)

Vajdaher, Fridrih "General museology”, Lviv, (2005). (in Ukrainian)

Kalugina, T. "Art museum as a phenomen of culture", Sankt-Peterburg, (2001). (in Russian)

Kepin, Dmytro "The contribution of I. Neustupny in the development of museology", in The works of the Memorial objects research center, Kyiv, No. 17. (2010): 177-184. (in Ukrainian)

Klymyshyn, Oleksandr "Aktual problems of the museology of the natural history'

Scientific proceedings of the State museum of natural history, Lviv, No. 26, (2010): 3-14. (in Ukrainian)

Mankovska, Ruslana "Museology as a scientific discipline: modern discourse and the problem of scientific integration", in The Journal of local studies, No. 3-4, (2009): 136-144. (in Ukrainian)

Maroevic I. "Museology as a discipline of informational science", in "Nordisk museologi", No. 2, (1997): 83, http://www.journals.uio.no/index.php/museolog/.../3105 
ISSN 2078-6077. Наукові зошити історичного факультету Львівського університету. 2018-2019. Випуск 19-20. Proceedings of History Faculty of Lviv University. 2018-2019. Issue 19-20.

Museology. Historical museums. - Moscow, 1988. (in Russian)

van Mensh, Peter 'On the metodology of museology', in The questions of museology, No. 1(9), (2014) (in Russian)

van Mensh, Peter “The object of museology”, in The questions of museology, No. 1(9), (2014) (in Russian)

Omelchenko, Urij. "The first sub-system of museum activity (theoretical base, source, development)", in Studies in culturology, Kyiv, vyp. 2, (1999): 288-311. (in Ukrainian)

Sapanzha, Olga "The contemporary Russian museology: tactical results and strategic foresights", in The Bulletin of Belorussian state university of culture and art, No. 2 (24), (2015): 182-189. (in Russian)

Sapanzha, Olga "Cultorological dimension of museum: the morphology of museality", in The questions of museology, No. 2 (4), (2011): 3-13. (in Russian)

Sapanzha, Olga, "Historiography of museology, museum studies, museography: On the problem of differentiation", in The questions of museology, No. 2 (8), (2013): 197-205. (in Russian)

Sapanzha, Olga "Contemporary theoretical museology: on the question of methodology", http://www.cyberleninka.ru/article/n/sovremennoe... (in Russian)

Smykova, E. "Theoretical-methodological approaches at the study of the museum as a socoicultural phenomen", in Social and humanitarian bulletin of Caspian region: scientific magazine, 1 (2), (2105), 27-38. (in Russian)

Shliahtina, L. "Modern museology: horizons of theory", in The questions of museology, No. 1 (7), (2013). (in Russian)

Shrajner, Klaus "The subject of research in museology and the origin of the discipline", in The museology. Museums of the world, Moscow, (1991).

Stranski, Zbinek. "Theoretical bases of museology as a science", in International symposium "Museology. The new ways - new aims", Boodensee, Switzerland, May, 11-14, 1988. 39-47. http://prostir.museum/ua/post/27922

Usenko, Pavlo "Museology - science, discipline image or the aggregate of verbal forms?" In The Bulletin of Dnipropetrovsk university, issue No. 18, (2010); 292-299. (in Russian)

Washborn, W. E. "Grandmotherology and museology", in Curator, No. 10 (1), (1967): 43-48. 
